\title{
The Duration of Reading the Qur'an with the Stress Levels in Medical Faculty Students in Palembang
}

\author{
Durasi Membaca Al The Qur'an dan Tingkat Stres pada Mahasiswa Fakultas Kedokteran di \\ Palembang
}

\author{
Ahmad Ghiffari ${ }^{1}$, Syahrul Muhammad ${ }^{2}$, M. Avif Ababil ${ }^{3}$ \\ ${ }^{1}$ Department of Parasitology, Faculty of Medicine, University of Muhammadiyah Palembang, Indonesia \\ ${ }^{2}$ Department of Public Health, Faculty of Medicine, University of Muhammadiyah Palembang, Indonesia \\ ${ }^{3}$ Faculty of Medicine, University of Muhammadiyah Palembang, Indonesia
}

DATA OF ARTICLE:

Received: 25 Jun 2020

Reviewed: 04 Sept 2020

Revised: 09 Des 2020

Accepted: 23 Feb 2021

\section{*CORRESPONDENCE:}

ahmad_ghiffari@um-

palembang.ac.id

DOI:

10.18196/mmjkk.v21i1.8488

TYPE OF ARTICLE:

Research
Abstract: The level of stress in each education programs differ between medical students and other scholars. Students should able to cope to normalize their stress. The study aims to determine the relationship between the duration of reading the Qur'an with the level of stress on students. The study design was a cross-sectional study, with a simple random sampling. The collecting data technique was using the Depression Anxiety Stress Scale (DASS) questionnaires and duration questionnaires followed by the chi-square analysis. The respondents are 90 medical students of Universitas Muhammadiyah Palembang. The results showed that the duration of reading the Qur'an among students is poor, and the moderate duration is correlated with a good stress level $(\mathrm{p}=0.002)$. Concluded that there is a relation to the duration of reading The Qur'an with the level of stress in medical students.

Keywords: depression anxiety stress scale; reading Qur'an; correlation; coping mechanism

\begin{abstract}
Abstrak: Tingkat stres pada mahasiswa kedokteran cenderung lebih tinggi dibandingkan dengan progam pendidikan lainnya. Mahasiswa harus mampu mengendalikan tingkat stres, untuk mendapatkan prestasi yang baik. Penelitian ini bertujuan untuk mengetahui hubungan intensitas membaca Al-Qur'an dengan tingkat stres pada mahasiswa di Fakultas Kedokteran Universitas Muhammadiyah Palembang. Desain penelitian ini merupakan penelitian cross sectional dengan simple random sampling. Teknik pengumpulan data menggunakan kuisioner, yaitu DASS dan kuesioner durasi membaca Al-Qur'an. Analisis data yang digunakan adalah chi square. Hasil penelitian ini menunjukkan bahwa intensitas membaca Al-Qur'an pada mahasiswa di Fakultas Kedokteran Universitas Muhammadivah Palembang tergolong kurang baik dengan tingkat stres yang cukup tinggi. Didapatkan pula durasi yang moderat dalam membaca Al-Quran berhubungan dengan tingkat stres yang baik $(p=0.002)$. Disimpulkan bahwa terdapat hubungan antara durasi membaca Al-The Qur'an dengan tingkat stres.
\end{abstract}

Kata Kunci: depression anxiety stress scale; membaca Qur'an; korelasi; kendali stres 


\section{INTRODUCTION}

Students around the globe experience depression, anxiety, and stress academic, prevalence estimates that the emotional disorder in medical students is higher than in the general population. ${ }^{2-10}$ The law students who come from poor families undergoing five years of education are known to suffer many psychological disorders. ${ }^{1}$ Nursing students are known for the difficulty to maintain professinalism due to highstress levels at work, ${ }^{11}$ various studies among medical students showed high-level stress when compared with other courses in the non-medical. ${ }^{12}$

Mental disorders in college students and doctors are closely related to the safety of patients. ${ }^{3}$ The duration of medical education programs associated with an increased incidence of depression, anxiety, and stress. ${ }^{1}$ Fatigue is associated with increased physical activity of medical students at the campus. ${ }^{4}$ Fatigue

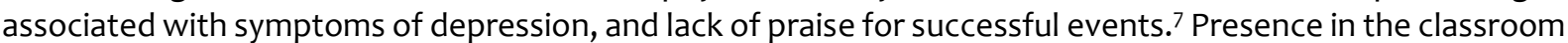
is not associated with the low incidence of stress in medical students. ${ }^{2}$ Factors related to the occurrence of anxiety are academic achievement, parental education, and cultural background..$^{13}$ Stress in the first year of education is often due to a lack of learning strategies, less sleep on the night before the test, and the low quality of the food consumed during the course. ${ }^{9}$

Coping with religious teaching is known to reduce stress in medical students, also helps in difficult decision-making circumstances, and encourages students to prioritize patients. ${ }^{14}$ Meditation can calm the mind is one way to reduce stress on students..$^{15}$ Meditation with the control of breath and yoga are recommended to improve agility and enhance the professionalism of nursing services. ${ }^{11}$ Mind meditation programs for therapists and healthcare providers reduce stress levels. ${ }^{16}$ Read the holy book of The Qur'an by the Moslems can get peace. ${ }^{17}$

Eustress is adopted after going through the process of adaptation stress.$^{18}$ Muslims in overcoming the problem and stressful condition is to read the Qur'an. ${ }^{19}$ Read verses from the Qur'an have a significant positive impact on the physiological and psychological changes when practiced every day regularly and continuously. ${ }^{20}$ Effects on reading the verses of the Qur'an are influenced in the duration. ${ }^{17}$ Need to investigate the relationship between the duration of reading the Qur'an with the level of stress in medical students in Palembang.

\section{MATERIAL AND METHOD}

The study used a cross-sectional research design, with whom respondents were students of the Faculty of Medicine, Universitas Muhammadiyah Palembang. The sampling technique used simple random sampling, with the instrument of the questionnaire to determine the duration of reading the Qur'an and the Depression Anxiety Stress Scale (DASS) PsyToolkit. The duration of reading The Qur'an is classified into good and poor, while the DASS is categorized into mild, moderate, and severe stress levels.

The inclusion criteria were medical students and those who were able to read the Qur'an. The exclusion criteria were students who had a history of mental disorders such as bipolar disorder and major depression, students who did not have a good relationship with their parents, students who had problems with their financial conditions, and students who failed in 3 classes.

The analysis was the univariate and bivariate chi-square test. Univariate determines the characteristics of the subject of gender research, the duration of reading the Qur'an, and the level of stress, while the bivariate analysis to determine the relationship between the duration of reading the Qur'an and the stress levels.

\section{RESULT}

Ninety students participated in the study. The results were the relations of gender with duration reading the Qur'an (Table 1) and the relation of duration reading the Qur'an with stress level (Table 2). 
Tabel 1. Relations of Gender with Duration Reading the Qur'an (NA = 90)

\begin{tabular}{lcccc}
\hline & \multicolumn{2}{c}{$\begin{array}{c}\text { Duration Category of Reading the } \\
\text { Qur'an }\end{array}$} & Total & p-value \\
\cline { 2 - 3 } & Poor & Good & & \\
\cline { 2 - 4 } & 29 & 41 & 70 & \\
Female & 18 & 2 & 20 & 0.000 \\
Total & 47 & 43 & 90 & \\
\hline
\end{tabular}

The result in Table 1 shows a significant relationship between gender and duration of reading the Qur'an with the $p$-value of $0.000(p<0.05)$. Female seemed to read the Quran more with a good duration.

Table 2. Relation of Duration Reading the Qur'an with Stress Level

\begin{tabular}{|c|c|c|c|c|c|c|}
\hline & & \multicolumn{3}{|c|}{ Stress level } & \multirow{2}{*}{ Total } & \multirow{2}{*}{ p-value } \\
\hline & & Mild & Moderate & Severe & & \\
\hline Duration & Poor & 14 & 24 & 9 & 47 & \\
\hline $\begin{array}{l}\text { Category of } \\
\text { Reading } \\
\text { the Qur'an }\end{array}$ & Good & 27 & 8 & 8 & 43 & 0.002 \\
\hline Total & & 41 & 32 & 17 & 90 & \\
\hline
\end{tabular}

The result in Table 2 concluded a significant relationship between the duration of reading the Qur'an with the level of stress with the $p$-value was $0.002(p<0.05)$. Good duration of reading the Qur'an related to the moderate stress level.

\section{DISCUSSION}

Our analysis showed that more female students read the Qur'an with a good duration. There was no previous study to relate the connection between gender and duration of reading the Qur'an, nonetheless, several more females entering the medical faculty seem to affect our result. ${ }^{21}$ Studies on gender to associate with the effect on duration read the Qur'an is more to the pregnant woman. ${ }^{22,23}$ It can not be concluded that gender-related to the level of duration read the Qur'an, albeit more studies were on women to further cohere the effect on duration read the Qur'an to the health condition.

Our scrutiny showed that a good duration of reading The Qur'an related to moderate stress levels. Earlier results display that medical student was in moderate stress. ${ }^{24} \mathrm{~A}$ comparable result to senior high school, ${ }^{25}$ that reading the Qur'an can reduce stress with a value of $p=0.007$. The duration of reading the Qur'an has a relationship to the stress level.

The duration in reading the Qur'an is unfortunately poor. Despite that, it has a relationship to stress level and student learning outcomes. ${ }^{26} \mathrm{~A}$ study in Islamic studies indicated that half of the students' abilities are still not good in reading the Qur'an following tajwid rules. ${ }^{27}$ It recommends designing effectively and efficiently the Qur'an learning. The duration of reading the Qur'an should be improved while it has relation for coping the stress and better learning outcomes..$^{26,28}$

The limitation to the study that the sample size and the analysis curb. The uneven participants who are more women might impair the result. The chi-square test can be miss leading to conclude the findings and a detailed analysis involving more variables should be applied to a vivid outcome. 


\section{CONCLUSION}

There is a relationship between the duration of reading the Qur'an and the level of stress. The duration of reading the Qur'an among medical students is unfortunately poor. It recommends designing an effectively and efficiently Qur'an learning, to improve the student's duration on reading the Qur'an.

\section{ACKNOWLEDGEMENT}

Thanks to dr. Hibsah Ridwan, M.Sc which help the analysis, and to all students as willing to participate the research.

\section{REFERENCES}

1. Wai H, Chan Q, Fun C, Sun R, Wai H, Chan Q. Irrational Beliefs, Depression, Anxiety, and Stress among University Students in Hong Kong. J Am Coll Heal. 2020; 0 (0): p. 1-15. https://doi.org/10.1080/07448481.2019.1710516

2. Abdulghani HM, AlKanhal AA, Mahmoud ES, Ponnamperuma GG, Alfaris EA. Stress and Its Effects on Medical Students: A Cross-sectional Study at a College of Medicine in Saudi Arabia. J Heal Popul Nutr. 2011; 29 (5): 516-22. https://doi.org/10.3329/jhpn.v29i5.8906

3. Shoua-Desmarais N, Harscher H Von, Rivera M, Felix T, Havas N, Rodriguez P, et al. First Year Burnout and Coping in One US Medical School. Acad Psychiatry. 2020; https://doi.org/10.1007/s40596-020-01198-w

4. Macilwraith P, Bennet D. Burnout and Physical Activity in Medical Students. Ir Med J. 2018; 111 (3): $707-15$.

5. Ranasinghe P, Wathurapatha WS, Mathangasinghe Y, Ponnamperuma G. Emotional Intelligence, Perceived Stress and Academic Performance of Sri Lankan Medical Undergraduates. BMC Med Educ. 2017; 17 (41): p. 1-7. https://doi.org/10.1186/s12909-017-0884-5

6. Shaikh BT, Kahloon A, Kazmi M, Khalid H, Nawaz K, Khan NA, et al. Students, Stress and Coping Strategies: A Case of Pakistani Medical School. Educ Heal. 2004; 17 (3): p. 346-53. https://doi.org/10.1080/13576280400002585

7. Haldorsen H, Bak NH, Dissing A, Petersson B. Stress and Symptoms of Depression among Medical Students at the University of Copenhagen. Scand J Public Health. 2014; 42 (September 2013): p. 89-95. https://doi.org/10.1177/1403494813503055

8. Loubir D Ben, Serhier Z, Diouny S, Battas O, Agoub M, Othmani MB. Prevalence of Stress in Casablanca Medical Students: a Cross-sectional Study. Pan Afr Med J. 2014; 19 (149): p. 1-10. https://doi.org/10.11604/pamj.2014.19.149.4010

9. Nechita F, Nechita D, Pirlog M-C, Rogoveanu I. Stress in Medical Students. Rom J Morphol Embryol. $2014 ; 55$ (3 suppl): 1263-6.

10. Gupta R, Singh N, Kumar R. Longitudinal Predictive Validity of Emotional Intelligence on First Year Medical Students Perceived Stress. BMC Med Educ. 2017; 17 (139): p. 1-6.

11.van der Riet P, Levett-Jones T, Aquino-Russell C. The Effectiveness of Mindfulness Meditation for Nurses and Nursing Students: An Integrated Literature Review. Nurse Educ Today. 2018; 65: $201-11$. https://doi.org/10.1016/j.nedt.2018.03.018

12. Wulandari FE, Hadiati T, Sarjana W. Hubungan antara Tingkat Stres dengan Tingkat Insomnia Mahasiswa/I Angkatan 2012/2013 Program Studi Pendidikan Dokter Fakultas Kedokteran Universitas Diponegoro. J Kedokt Diponegoro. 2017; 6 (2): 549-57. https://doi.org/10.35790/ebm.2.1.2014.3696

13. Yusoff MSB, Abdul Rahim AF, Baba AA, Ismail SB, Mat Pa MN, Esa AR. Prevalence and Associated Factors of Stress, Anxiety, and Depression among Prospective Medical Students. Asian J Psychiatr. 2013; 6 (2): 128-33. https://doi.org/10.1016/j.ajp.2012.09.012

14. Ray C, Wyatt TR. Religion and Spirituality as a Cultural Asset in Medical Students. J Relig Health. 2018; https://doi.org/10.1007/s10943-017-0553-3

15. Huberty J, Green J, Glissmann C, Larkey L, Puzia M, Lee C. Efficacy of the Mindfulness Meditation Mobile App " Calm " to Reduce Stress Among College Students: Randomized Controlled Trial. JMIR Mhealth Uhealth. 2019; 7 (6): p. 1-17. https://doi.org/10.2196/14273

16.Yang E, Schamber E, Meyer RML, Gold JI. Happier healers: Randomized Controlled Trial of Mobile Mindfulness for Stress Management. J Altern Complement Med. 2018; 24 (5): 505-13. ttps://doi.org/10.1089/acm.2015.0301 
17. Irawati K, Madani F. Durasi Membaca Al- Qur ' an dengan Fungsi Kognitif pada Lansia. Mutiara Med. 2019; 19 (1): 17-22.

18. Kupriyanov R V, Sholokhov MA, Kupriyanov R, Zhdanov R. The Eustress Concept: Problems and Outlooks. World J Med Sci. 2014; 11 (2): 179-85.

19. Mukarramah. Hubungan Aktifitas Fisik dan Intensitas membaca Al-Qur'an Terhadap Fungsi Kognitif Lanjut Usia. Makassar: Fakultas Kedokteran dan Ilmu kesehatan UIN Alauddin; 2016.

20. Khan N, Ahmad NB, Beg AH, Fakheraldin MAI, Alla ANA, Nubli M. Mental and Spiritual relaxation by recitation of the holy Quran. In: 2nd International Conference on Computer Research and Development, ICCRD 2010. 2010. p. 863-7. https://doi.org/10.1109/ICCRD.2010.62

21. Pinasthika A, Findyartini A. Hubungan antara jenis kelamin dan asal daerah dengan mekanisme Coping mahasiswa tahun pertama program studi pendidikan dokter FKUI tahun akademik 2015/2016. Perpipki (Perhimpunan Pengkaji Ilmu Pendidik Kedokt Indones. 2018; 6 (1).

22. Setiowati W, Asnita N. Pengaruh terapi Murottal Al-Qur'an surah Maryam terhadap tingkat kecemasan pada ibu hamil trimester III. Darur Azhar. 2020; 9 (1): 77-83. https://doi.org/10.35890/jkdh.v9i1.148

23. Untari MM, Rohmah FA. Kecemasan ibu hamil ditinjau dari intensitas membaca Al-Qur'an dan kelompok usia. Humanitas (Monterey N L). 2016; 13 (1): 13-21. https://doi.org/10.26555/humanitas.v13i1.3834

24. Legiran L, Azis MZ, Bellinawati N. Faktor Risiko Stres dan Perbedaannya pada Mahasiswa Berbagai Angkatan di Fakultas Kedokteran Universitas Muhammadiyah Palembang. J Kedokt dan Kesehat. 2015; 2 (2): 197-202.

25. Nugraheni D, Mabruri MI, Stanislaus S. Efektivitas Membaca Al-Qur'an untuk Menurunkan Stres Akademik pada Siswa kelas XI SMA negeri 1 Kebumen. Intuisi J Psikol Ilm. 2018; 10 (1): 59-71.

26. Suherman S. Pengaruh kemampuan membaca Al Qur'an terhadap hasil belajar mahasiswa politeknik negeri Medan. Ansiru. 2017; 1 (2): 1-7.

27. Wirdati W, Rivauzi A, Anwar F, Kosasih A. The Student's Ability to Read the Qur'an at Islamic Education Program Universitas Negeri Padang (A Need Assessment Study). In: International Conference on Public Administration, Policy and Governance. 2020. p. 370-6. https://doi.org/10.2991/aebmr.k.200305.221

28. Suherman S, Lubis MAF. Hubungan Kemampuan Membaca AlQur'an dengan Hasil Belajar Mahasiswa Program Studi Teknik Mesin Politeknik Negeri Medan. Studi Kasus pada Politeknik Negeri Medan. Integritas. 2017; 3 (2): 1-26. 